\title{
Molecular cloning and expression patterns of the cholesterol side chain cleavage enzyme (CYP11A1) gene during the reproductive cycle in goose (Anas cygnoides)
}

Qi Xu, Yadong Song, Yang Chen, Ran Liu, Yang Zhang, Yang Li, Zhengyang Huang, Wenming Zhao, Guobin Chang and Guohong Chen*

\begin{abstract}
Background: CYP11A1, a gene belonging to the family 11 of cytochrome P450, encodes a crucial steroidogenic enzyme that catalyzes the initial step in the production of all classes of steroids. Many studies show that CYP11A1 plays a role in ovary function. However, the role of CYP11A1 in goose reproductive cycle remains largely unknown.

Results: In this study, full-length CYP11A1 CDNA of Zhedong goose was obtained using reverse transcription polymerase chain reaction (RT-PCR) and rapid amplification of cDNA ends (RACE). The cDNA consisted of a 96-base pair (bp) 5'untranslated region (UTR), a 179-bp 3'UTR and a 1509-bp open reading frame. The open reading frame encodes a putative 503 amino acid protein that shares high homology with CYP11A1 of other birds. The amino acid sequence possesses conserved domains of the P450 superfamily, which include the steroid-binding domain and the heme-binding region. Real-time quantitative polymerase chain reaction (qPCR) analysis revealed CYP11A1 mRNA was expressed ubiquitously in every Zhedong goose tissue analyzed, including the heart, liver, glandular stomach, lung, spleen, kidney, intestinum tenue, intestinum crassum, cerebrum, cerebellum, muscle, oviduct, pituitary, hypothalamus and ovary.. The relatively low levels of CYP11A1 mRNA were detected in pituitary, ovary and oviduct tissues at ovulation when compared with levels at oviposition. Interestingly, higher expression was observed in ovary and oviduct tissues during brooding. Lastly, higher mRNA expression of Yangzhou geese was detected during the ovulation period than that of Zhedong geese.
\end{abstract}

Conclusions: Our findings reveal the sequence characterization and expression patterns of the CYP11A1 gene during the goose reproductive cycle, which may provides correlative evidence that CYP11A1 expression is important in reproduction activity.

Keywords: CYP11A1, Gene expression, Goose, Reproduction

\footnotetext{
* Correspondence: ghchen@yzu.edu.cn

Key Laboratory of Animal Genetics and Breeding and Molecular Design of Jiangsu Province, Yangzhou University, Yangzhou 225009, PR China
} 


\section{Background}

Cytochrome P450 side chain cleavage (P450scc, encoded by the CYP11A1 gene) plays a major role in the regulation of steroidogenesis by mediating the conversion of cholesterol to pregnenolone [1]. Because of its physiological importance, CYP11A1 has been the focus of many studies. Recently, more and more evidence shows that CYP11A1 plays a role in ovary function. In fowl, many investigations have found that CYP11A1 expression changes dynamically in developing follicles [2-4] and that its expression in ovarian granulosa cells is influenced largely by hormonal regulation [5-9]. Another study found that the hormonally and developmentally regulated expression of CYP11A1 was principally driven by multiple trans-acting factors, like Sp-1 [10, 11], SF-1/LRH-1, GATA4, CREB1,AP-1 [12] AP-2, LBP-1b/LBP-9 [13] and Ff1b [14].

The goose (Anas cygnoides) is a commercially important food source that is widely cultivated in China. It is an ideal animal model for characterization of fowl reproduction because of obvious reproductive stages and strong broodiness [15]. In a previous study, we identified CYP11A1 as an important candidate gene through transcriptome profiling of ovaries from laying and brooding geese [16]. To further characterize the role of CYP11A1 in the goose reproductive cycle, we cloned Zhedong goose (Anas cygnoides) CYP11A1 and characterized its spatiotemporal expression patterns by Real-time qPCR. We also investigated the differences in CYP11A1 expression in high egg production breed(Yangzhou geese, Anas cygnoides) and low egg production breed(Zhedong goose). These data may facilitate a better understanding of expression patterns of the CYP11A1 gene during the reproductive cycle in goose.

\section{Methods}

\section{Ethics statement}

All animal experiments were reviewed and approved by the Institutional Animal Care and Use Committee of Yangzhou University. Procedures were performed in accordance with the Regulations for the Administration of Affairs Concerning Experimental Animals (Yangzhou University, China, 2012) and the Standards for the Administration of Experimental Practices (Jiangsu, China, 2008).

\section{Animals and tissue sample collection}

One hundred female Zhedong geese and Yangzhou geese were selected from the breeding farm of Jiangsu Lihua Animal Husbandry Co. Ltd (Changzhou, China)), which laid about thirty and seventy eggs, respectively. They were both housed semi-enclosed building and raised the same conditions according to the farm's standard practice. During the experiment, geese were fed ad libitum with rice grain supplemented with green grass or water plants whenever possible. The feed was provided during the daytime when the geese were released to an open area. The geese were exposed to natural light and ambient temperature throughout this study. The five 120-day-old young (prelaying) Zhedong female geese were sacrificed to investigate CYP11A1 expression patterns in different tissues. The Zhedong geese were anesthetized with sodium pentobarbital and the heart, liver, glandular stomach, lung, spleen, kidney, intestinum tenue, intestinum crissum, cerebrum, cerebellum, muscle, oviduct(infundibulum), pituitary, hypothalamus and ovary(stroma) were removed and immediately frozen in liquid nitrogen before storage at $-80{ }^{\circ} \mathrm{C}$ for RNA isolation. Tissue samples from the oviduct(infundibulum), pituitary gland, hypothalamus, and ovary(stroma) were obtained from twelve sacrificed 380-day-old adult geese, including three laying Zhedong geese with an egg in the oviduct (ovulation, the release of an ovum from a ruptured follicle), three laying Zhedong geese without an egg in the oviduct (oviposition, the laying of the egg), three brooding Zhedong geese, and three laying Yangzhou geese with an egg in the oviduct (ovulation). The tissue samples were obtained promptly, as described above, to characterize developmental expression patterns.

\section{Zhedong goose CYP11A1 CDNA cloning and sequencing}

Total RNA was extracted from collected tissue samples using TRIzol reagent according to the manufacturer's instruction (TaKaRa, China). The RNA was resuspended in RNase-free water, and the concentration and purity were determined using a NanoDrop Spectrophotometer (NanoDrop, USA). After purification, total RNA $(2 \mu \mathrm{g})$ was reverse transcribed using M-MLV reverse transcriptase (Promega, USA) according to the manufacturer's protocol. BLAST analysis of one unigene revealed that it was highly similar to the chicken CYP11A1 gene [17]. Primers were designed according the unigene (Table 1) and RT-PCR was performed using ovarian cDNA from geese. The PCR product was purified, cloned into the pMD19-T vector (TaKaRa, China), and subjected to sequence analysis. The $5^{\prime}$ and $3^{\prime}$ ends of CYP11A1 were amplified via rapid amplification of cDNA ends (RACE) using the SMART RACE cDNA amplification protocol (Clontech, USA) and the 3'-Full RACE Kit (TaKaRa, China), respectively. RACE primers (Table 1) were designed using the partial CYP11A1 nucleotide sequence obtained from RT-PCR. Touchdown and nested PCRs were performed according to the manufacturer's instructions. Amplicons were then cloned into a plasmid vector for nucleotide sequencing by Sangon Biotech (Shanghai, China).

\section{Sequence analyses}

The Zhedong goose CYP11A1 cDNA and the deduced amino acid sequences were analyzed using DNAssist (version 2.2) and the Expasy search program 
Table 1 Primers used for gene cloning and expression analysis

\begin{tabular}{lll}
\hline Primer name & Oligo sequences (5'-3') & Type \\
\hline cCYPF & GTCTGTGTGCATGTGCTGTACGG & Complete ORF \\
cCYPR & GTTGTCGGGAGGAGGATGAGGT & 5'RACE \\
5'Router & GAACTTGGGGCCATGATGT & 3'RACE \\
5'Rinner & CCCGCAGCCGGACGACC & Expression profile \\
3'Router & CAAGCACTTCAAGGGGCTGAGCTT & \\
3'Rinner & GACCAAGCGGGAGTGGAGTGGGACCA & \\
eCYP-F & TGCTGCAGGACTTGTGG & Expression profile \\
eCYP-R & TGGAGAGGATGCCCATGT & \\
GAPDH-F & GGTGGTGCTAAGCGTGTCAT & \\
GAPDH-R & CCCTCCACAATGCCAAAGTT &
\end{tabular}

(http://au.expasy.org/tools/), respectively. Homology analyses were carried out using Clustal W (http://www.ebi.ac.uk/Tools/msa/). The phylogenetic analyses and statistical neighbor-joining bootstrap tests of the phylogenies were performed using the MEGA package (version 6.0) and the bootstrap method was used to indicate confidence values for tree nodes based on 1000 replicates. The conserved domain analysis was predicted by SMART (http://smart.embl-heidelberg.de/).

\section{CYP11A1 mRNA expression patterns in Zhedong goose}

To study CYP11A1 mRNA expression, we performed Realtime qPCR on total RNA isolated from the tissues of prelaying Zhedong geese and the kidney tissue served as a calibrator tissue. Assays were conducted in $20 \mu \mathrm{L}$ reactions using the SYBR Premix Ex Taq ${ }^{\mathrm{TM}}$ (TaKaRa, China) and performed on an ABI two-step RT-PCR system (Applied Biosystems 7500, USA) with diluted first-strand cDNA. qPCR programs for CYP11A1 and glyceraldehyde-3phosphate dehydrogenase (GAPDH) were: 1 cycle of $95{ }^{\circ} \mathrm{C}$ for $5 \mathrm{~min}, 40$ cycles of $95^{\circ} \mathrm{C}$ for $10 \mathrm{~s}, 60{ }^{\circ} \mathrm{C}$ for $34 \mathrm{~s}$ data collection, followed by 1 cycle for melting curve analysis. All cDNA synthesis reactions were carried out using $100 \mathrm{ng}$ of total RNA per reaction and assayed in three to four technical replicates for each set of biological samples. The same methods were used to determine the Zhedong CYP11A1 mRNA expression profile during the reproductive cycle. The GAPDH gene served as an internal reference gene and the hypothalamus tissue from prelaying Zhedong geese served as a calibrator tissue for differential expression analyses. To analyze the difference of expression patterns between different egg production goose breeds(Zhedong geese and Yangzhou geese), the mean $\Delta \mathrm{Ct}$ value of the hypothalamus tissue of Zhedong geese within each group was used as the calibrator.

\section{Statistical analyses}

Statistical analyses were performed using t-tests independent of group and SPSS version 13.0 software.

\section{Results}

Zhedong goose CYP11A1 cDNA cloning and sequence analyses

To obtain the full-length cDNA of goose CYP11A1, RT-PCR and RACE were carried out. The CYP11A1 CDNA was only found to be 1784 nucleotides in length, which included a 96-nucleotide 5' UTR, a 179-nucleotide 3' UTR, and a 1509-nucleotide open reading frame putatively encoding a single 503 amino acid protein. The other transcript variant did not been found among the tissues tested in Zhedong goose.

\section{Phylogenetic analysis of the putative CYP11A1}

To evaluate the relationship between goose CYP11A1 and that of other birds, sequence alignment and phylogenetic analysis were carried out. Alignment of the amino acid residues of goose CYP11A1 with those of other birds forms is shown in Fig. 1. Goose CYP11A1 shared fairly high identity with birds orthologs (over $69 \%$ identity), including budgerigar ( $86.3 \%$ identity), chicken (85.6\% identity), penguin (85.2\% identity), turkey (84.8\% identity), rock pigeon (84.8\% identity), peregrine (84.7\% identity), crested ibis (84.4\% identity), peregrine (83.7\% identity), Tibetan ground-tit $(77.0 \%$ identity), Zebra Finch (76.8 \% identity), and Medium ground finch (69.7\% identity). Furthermore, the p450 domain (aa 38-495 in geese) was conserved in all birds sequences analyzed.

Phylogenetic analysis of CYP11A1 resulted in clear segregation into three groups, one branch containing mammalian CYP11A1, one branch of birds CYP11A1, another branch of fish CYP11A1(Fig. 2). Goose CYP11A1 clustered with other Phasianidae forms and appears to be significantly diverse from Paridae forms.

\section{Expression pattern of CYP11A1 in different tissues and reproductive cycle stages in Zhedong goose}

The qPCR demonstrated that CYP11A1 was ubiquitously expressed in fifteen tissues tested, but the expression 


\begin{tabular}{|c|c|}
\hline \multirow{13}{*}{$\begin{array}{l}\text { chicken } \\
\text { turkey } \\
\text { goose } \\
\text { peregrine } \\
\text { saker } \\
\text { penguin } \\
\text { crested-Ibis } \\
\text { pigeon } \\
\text { budgerigar } \\
\text { tibetan-ground-tit } \\
\text { zebra-finch } \\
\text { medium-ground-finch }\end{array}$} & $\longmapsto$ \\
\hline & -MLSRAAP--IAGSFQACRCAGG---IPALAGVH-_-YPLPSSSGARPFDQVPGEWRAGILNLYHFWKEGGFHNVHNIMASKFQRFGPIYREKLGVYESVNIISPRDAAT 101 \\
\hline & -MLSRAAP-IAGSFQACRCAGG--IPALTGVH- - CPLPSPPGARPFDQVPGEWRTGILNLYHFWKEGGFHNVHIMASKFQRFGPIYREKLGVYESVNIISPRDAAT 101 \\
\hline & MVFSRVFGTWVLPAILACSFLWG_-_-PPAPA-_-_AARPFEQVPGERRGGILNLYRFWQEGGLHNVHNIMARKFQRFGPIYREKLGVYESINIISPRDAAT 95 \\
\hline & -MLARAA-_-_GALRGWPPAPAGGCRRAGGAAS-_-PIPPAPRPFNQLPGDWRAGWLNLYRFWQEGGLHNVHIMARKFQQFGPIYREKLGVYESVNIISPQDAAT 98 \\
\hline & -MLARAA--_-GALRGWPPAPAGGCRRAGGAAS--_-PIPPAPRPFNQLPGDWRAGWLNLYRFWQEGGLHNVHHIMARKFQQFGPIYREKLGVYESVNIISPQDAAT 98 \\
\hline & -MLARAAP--KPGALRGCPPARAGGCRQTRGAATPS-_-_-HAPPIPPAPRPFNQLPGDWRAGWLNLYRFWQEGGLHNVHHIMARKFQQFGPIYREKLGVYESVNIISPRDAAT 106 \\
\hline & -MLARAAP--KPGTLRGCPLARAGGCHQTRGAATPL-_-_-RALPIPPTPRPFNQLPGDWRTGWLNLYRFWQEGGFHNVHHIMARKFQQFGPIYREKLGVYESVNIISPQDAAT 106 \\
\hline & -MLARATP--KPGALRGCPQALGRGCCRTQGTAT-- -PVPPTPRPFNQLPGDIRAGWLNLYRFWQEGGLHNVHHIMARKFQQFGPIYREKLGVNETVNIISPRDAAT 101 \\
\hline & -MPIPRPFNQLPGDWRAGWLNLYRFWQEGGLHNLHHIMARKFQQFGPIYREKLGVYESVNIITPRDAAT 68 \\
\hline & -MLALLAA--KPGALRGCPRAAAARCRRLGGTATAVPSAVPSAVPSAVPSAVPSAPRPFSQVPGEWRAGILNLYRFWQEGGLTNLHLIMARKFRQFGPIYREKLGVYESVNIISPGDAAT 117 \\
\hline & -MLARVVT--KPGALRGCPRGAAARCRRLGGAGG---AVPSAPRPFNQVPGEWRAGWLNLYRFWREGGLSALHLSMAQKFRRFGPIYREKLGVHETVNIISPGDAAT 101 \\
\hline & 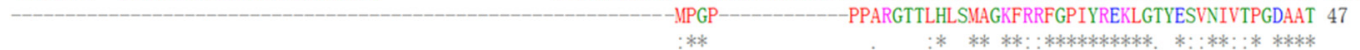 \\
\hline
\end{tabular}

chicken

turkey

goose

peregrine

saker

penguin

crested-Ibis

pigeon

budgerigar

tibetan-ground-tit

zebra-finch

medium-ground-finch

chicken

turkey

goose

peregrine

saker

penguin

crested-Ibis

pigeon

budgerigar

tibetan-ground-tit

zebra-finch

medium-ground-finch

chicken

turkey

goose

peregrine

saker

penguin

crested-Ibis

pigeon

budgerigar

tibetan-ground-tit

zebra-finch

medium-ground-finch

chicken

turkey

goose

peregrine

saker

penguin

crested-Ibis

pigeon

budgerigar

tibetan-ground-tit

zebra-finch

medium-ground-finch

LFKSEGMLPERFSVPPWVAYRDYRNKPYGVLLKTGEAWRSDRLTLNKEVLSPQVVDSFVPLLDQVSQDFLRRARAQVQQSGRERTTADFSHELFRFALESVCHVLYGERLGLLQDFVDPE 221 LFKSEGVLPERFSVPPWVAYRDYRNKPYGVLLKTGEAWRSDRLTLNKEVLSPQVVDSFVPLLNQVSEDFVQRARAQVQRSSRERWTADFSHELFRFALESVCHVLYGERLGLLQDFVDPE 221 LFRSEGMIPERFSVPPIVAYRDYRNKPYGVLLKKGEATRSDRL TLNKEVLSPQVVEGFYPLLSEVGEDFVRRARAQVOKSGRERWTADFSHELFRFALESVCHVLYGERLGLLQDFVDPE 215 LFQAEGTLPERFSVPPWVAYRDYRNKPYGVLLKTGEAWRSDRLVLNKEVLSPQVVESFVPLLSQVGEDFIQRARAQVGKSGRERWTADFTHELFRFALESVCHVLYGERLGLLQDFVDPE 218 LFQAEGTLPERFSVPPWVAYRDYRNKPYGVLLKTGEAWRSDRLYLNKEVLSPQVVESFVPLLSQVGEDFIQRARAQVVXXXXX-WTADFTHELFRFALESVCHVLYGERLGLLQDFVDPE 217 LFQAEGTLPERFSVPPWVAYRDYRNKPYGVLLKTGEAWRSDRLYLNKEVLSPQVVEGFVPLLSEVGEDFVRRARAQVGKSGRESWTADFTHELFRFALESVCHVLYGERLGLLQDFVDPE 226 LFQAEGTLPERFSVPPWVAYRDYRNKPYGVLLKTGEAWRSDRLVLNKEVLSPQVVEGFVPLLSEVGEDFVRRARAQVENSGRERWTADFTHELFRFALESVCHVLYGERLGLLQDFVDPE 226 LFQAEGTLPERFRVPPWVAYRDYRNKPYGVLLKKGEAWRSDRLLLNKEVLSPQAVESFVPLLSAVGEDFVRRARAQVGQSGRERITADFTHELFRFALESVCHVLYGERLGLLQDFVDPE 221 LFQAEGTLPERFSVPPWVAYRDYRNKPYGVLLKTGEAWRSDRLVLNKEVLSPQVVEGFVPLLSQVGDDFIRRARAQVGKSGREYWTADFTHELFRFALESVCHVLYGERLGLLQDFVDPE 188 LFQAEGTLPERFSVPPWVAYRDFRNKPYGVLLKTGEAWRSERLLLNKEVLAPEAVPGFVPLLSAVAEDFVRRARAQARQSGRQCWTADFSQELFRFALESVCHVLYGQRLGLLQDFVEPE 237 LFQAEGALPERFRVPPWVAYRDFRNKPYGVLLKTGEAWRSDRLLLNQEALAPAAVAAFVPLLSAVGEDFVRRARAQARHSGHGCWTGDFSHELFRFALESVCHVLYGQRLGLLQDFVQPE 221 LFQAEGALPERFRVPPWAYRDFRNKPYGVLLKVP-PQKPQTLRRAAQVSGDPKNGAGTPNLDSS-REWVPQIQAPQG-SAHXCWSGDFSQELFRFALESVCHVLYGERLGLLQDFVQPE 164

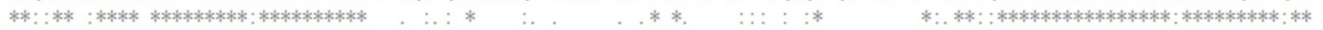

AQQFIDAVTLMFHTTSPYLYVPPALLRHLNTKTWRDHVHAWDAIFTQADKCIQNVYRDIR LQRKSTEEHTGILFSLLVQDKLPLDDIKASVTEMMAGGVDTTSUTLQWAVLELARSPGIQ 341

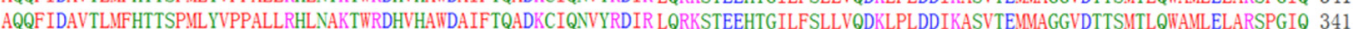
AQRFIDAVTLMFHTTSPYLYLPPALLRGLNTRTWRDHVHAWDAIFTQADKCIQNVYRDLR LQRKSSREYMGILSSLLLQDKLPLDDIKASVTEMMAGGVDTTSVTLQINAMFELARSPGTQ 335 AQRFIDAVTLMFHTTSPYLYLPPALLRHLNAKMWRDHVRAIDAIFSQADKCIQNVYRDLR LQRKSTKEYMGILCSLIMQDKLPLDDIKASVTEMMAGGVDTTSMTLQINAMFELARSPGVQ 338 AQRFIDAVTLMFHTTSPMLYLPPALLRHLNAKMWRDHVRAIDAIFSQADKCIQNVYRDLR LQRKSTKEYMGILCSLIMQDKLPLDDIKASVTEMMAGGVDTTSMTLQIVAMFELARSPGVQ 337 AQRFIDAVTLMFHTTSPMLYLPPALLRHLNAKTWRDHVQAWDAIFTQADKCIQNVYRDLR LQRKSTKEYMGILCSLIMQDKLPLDDIKASITEMMAGGVTTSMTLQWNAMFELARSPGIQ 346 AQRFIDAVSLMFHTTSPYLYLPPALLRHLNAKTWRDHVQAIIDAIFTQADKCTQNVYRDLR LQRKSTNEYMGILCSLTMQDKLPLDDIKASITEMMAGGVDTSYTLQWAMFELARSPGIQ 346 AQRFIDAVTLYFHTTSPULYLPPALLRHLNTKTWRDHVWAIIDAIFSQADKCIQNVYRDLR LQRKSTTEYMGILCSLIMQDKLPLDDIRASVTEMMAGGVDTSMTLQWAVFELARSPGVQ 341 AQRFIDAVALYFHTTSPYLYLPPALLRHLNAKTWRDHVWAWDAIFSQADKCIHNVYRDLR LQRKSTTEYMGILCSLILQDKLPLDDIKASVTEMMAGGVDTTSMTLQINAMFELARAPAVQ 308 AQRFIEAVSRMFHTTAPMLHLPPALLRRLNTRTWRQHVQAWDVIFCQADKCIQNVYRELR LRHRSAQEHVGILGNLILRARLPLDDIRASVTEMMAGGVDTSSITQWINLLLARAPGVQ 357 AQRFIEAVARYFHTTAPMLYLPPALLRRLRSRTWREHVHAWDAIFCQADKCIQNVYRDLR LQRKSSQEYMGILGNLILRDKLPLDDIRASVTEMMAGGVDTTSMTLQIVAMLELARAPGVQ 341 AQRFIEAVSRMFHTTAPMLYLPPALLRRLRSHTWRQHVQAIIDAIFYQADKCIQNX-RAVRLQRKSRQEHVGILGNLILRDKLPLDDIRASVTEMMAGGVDTTSMTLQIVAMLELARAPGVQ 283

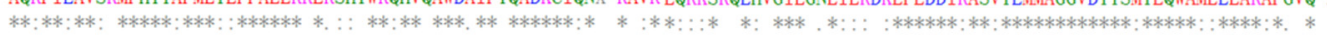

ERLRAEVLAAKQEAQGDRVKVIKSTRLLKAATKETL RLHPVAVTLQRYTTQEVILQDYRIPPKTLVQVGLYAMGRDPEVFPKPEQFNPERILLVMGSKHFKGLSFGFGPRQCLGRRIAELE 461 ERLRAEVLAAKQEAQGDRVKMLKSIRLLKATIKETLRLHPVAVTLQRYTTKEVILQDP-HPPKTLVQVGLYAMGRDPEVFPKPEQFNPERILVVGSKHFKGLSFGFGPRQCLGRRIAELE 460 EQLRTEVLAAKHKVAGDRVKMLKTTPLLKAAIKETLRLHPVAVTLQRYTVQEVVLQDYRIPPKTLVQVGLYAMGRDPEVFPKPEQFSPERIILLPGSKHFKGLSFGFGPRQCLGRRIAELE 455 EQLRAEVLAAKQEAAGDRVKMLKTIRLLKATIKETLRLHPVAVTLQRYTTQEVILQDYRI PPKTLVQVGLYAMGRDPEVFPKPEQFSPQRIILAAGPKHFKGLSFGFGPRQCLGRRIAELE 458 EQLRAEVLAAKQEAAGDRVKMLKTIRLLKATIKETLRLHPVAVTLQRYTTQEVILQDYRIPPKTLVQVGLYAMGRDPEVFPKPEQFSPQRIILAAGPKHFKGLSFGFGPRQCLGRRIAELE 457 EQLRAEVLAAKREAAGDRVKYL KTIRLLKAAIKETL RL HPVAVTLORYTYOEVILODYRIPPKTLVQVGLYAMGRDAKVFPKPEQFSPQRIILAAGPKHFKGLGFGFGPRQCLGRRIAELE 466 EQLRAEVLAAKREAAGDRVMLKTIRLLKAAIKETLRLHPVAVTLQRYTMQEVILQDYRIPPKTLVQVGLYAMGRDAEVFPKPEQFSPQRILAAGPKHFKGLGFGFGPRQCLGRRIAELE 466

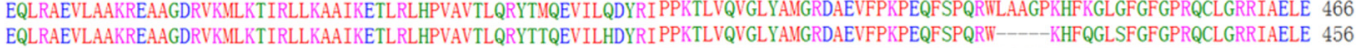
EQLRAEVLAAKREAAGDRGKMLKSIRLLKAAIKETLRLHPVAVTLQRYTTQEIILQDYRI PPKTLVQVGLYAMGRDPEVFPKPEQFIPQRIILGADPKHFKGLGFGFGPRQCLGRRIAELE 428 EQLRAEVLAAKRETGGDREKMLKSTRLLKAAIKETLRLHPVAVTLQRYTTHEVILQEYRIPARTLVQVGLYAMGRDPAVFPKPEQFWPQRILAAGPKHFQGLGFGFGPRQCLGRRIAELE 477 EQLRAEVLAAKREAGGDREKMLKSTRLLKATIKETLRLHPVAVTLQRYTTHEVILQDYRIPPGTLVQVGLYAMGRDPDVFPRPERFRPQRILAAGPKPFLGLGFGFGPRQCLGRRIAELE 461 EQLRAEVLAAKREAGGDREKMLKSTRLLKATIKETLRLHPVAVTLQRYTTQEVILQDYRIPPG--

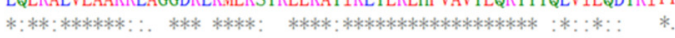

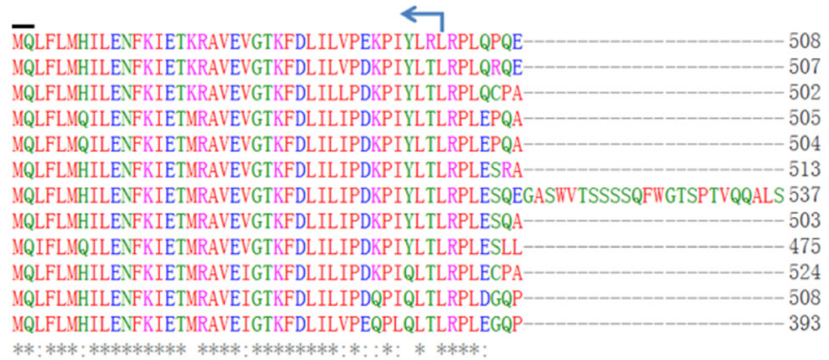

Fig. 1 Alignment of the deduced amino acid sequence of goose CYP11A1 with those of the other birds species. Additional Genbank accession numbers not mentioned elsewhere are as follows: chicken(Gallus gallus,NM_001001756.1), turkey(Meleagris gallopavo,XR_118355.1), penguin (Aptenodytes forsteri,XM_009278905.1), crested ibis(Nipponia Nippon, XM_009469738.1), peregrine(Falco peregrinus, XM_005239431.1), rock pigeon(Columba livia, XM_005513042.1), budgerigar(Melopsittacus undulates,XM_005145776.1), saker(Falco cherrug,XM_005437500.1), Tibetan ground-tit (Pseudopodoces humilis, XM_005521726.1), Zebra Finch(Taeniopygia guttata, NM_001127374.1) and Medium ground finch(Geospiza fortis, XM_005430050.1) The asterisk indicates residues that are identical among all birds. Dashes indicate gaps introduced to facilitate alignment. Arrows highlight the p450 domain, the steroid-binding domain (I), and the heme-binding region (II) 


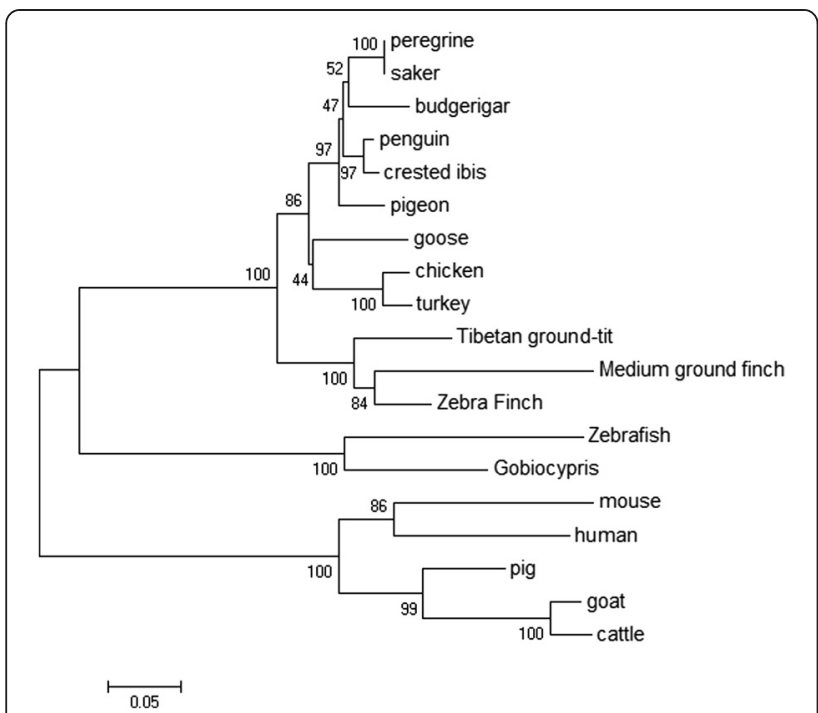

Fig. 2 Phylogenetic analysis of CYP11A1 proteins. Phylogenetic tree constructed based on ClustalW alignment of the deduced amino acid sequences of CYP11A1 from different birds. The reliability of the neighbor-joining tree was estimated by bootstrap analysis with 1,000 replicates. Bootstrap values are shown on the lineages of the tree and major taxonomic clusters are indicated separately. Additional Genbank accession numbers not mentioned elsewhere are as follows: mouse(Mus musculus, NM_019779.3), zebrafish (Danio rerio, AF527755.1), gobiocypris(Gobiocypris rarus, JN858106), human (Homo sapiens,NM_000781), pig(Sus scrofa,NM_214427), goat (Ovis aries,NM_001093789) and cattle(Bos Taurus, NM_176644). The scale bar indicates $5 \%$ amino acid divergence in sequence levels were distinctly different (Fig. 3). High levels of CYP11A1 transcript were detected in ovary, oviduct, pituitary, hypothalamus, lung, and spleen tissues in Zhedong goose, and lower negligible expression levels were found in heart and muscle tissues (Fig. 3).

To furtherly determine temporal expression patterns we characterized CYP11A1 expression in the ovary, oviduct, pituitary, and hypothalamus tissues during different stages of the goose reproductive cycle (prelaying, ovulation, oviposition, and broody periods). We observed different CYP11A1 expression profiles in the different tissues at different times of the reproductive cycle (Figs. 4). From an overall perspective, it was relatively low during the ovulation period (Fig. 4). In the pituitary tissue, CYP11A1 mRNA levels are relatively high during the prelaying period, and steadily decline through the egg laying period. In the ovary, CYP11A1 mRNA levels dropped to an approximate tenfold decrease during the ovulation period followed by a significant increase during the oviposition period. In the oviduct, CYP11A1 mRNA levels were relatively high during the broody period and relatively low during the prelaying period. In the hypothalamus, CYP11A1 mRNA levels remained low throughout the entire reproductive cycle.

\section{Comparison on CYP11A1 tissue-differential expression between Zhedong geese and Yangzhou geese in ovulation period}

Additionally, to explore the differences in CYP11A1 expression in different goose breeds, its expression levels were compared in Zhedong geese (low egg production) and Yangzhou geese (high egg production) in ovulation

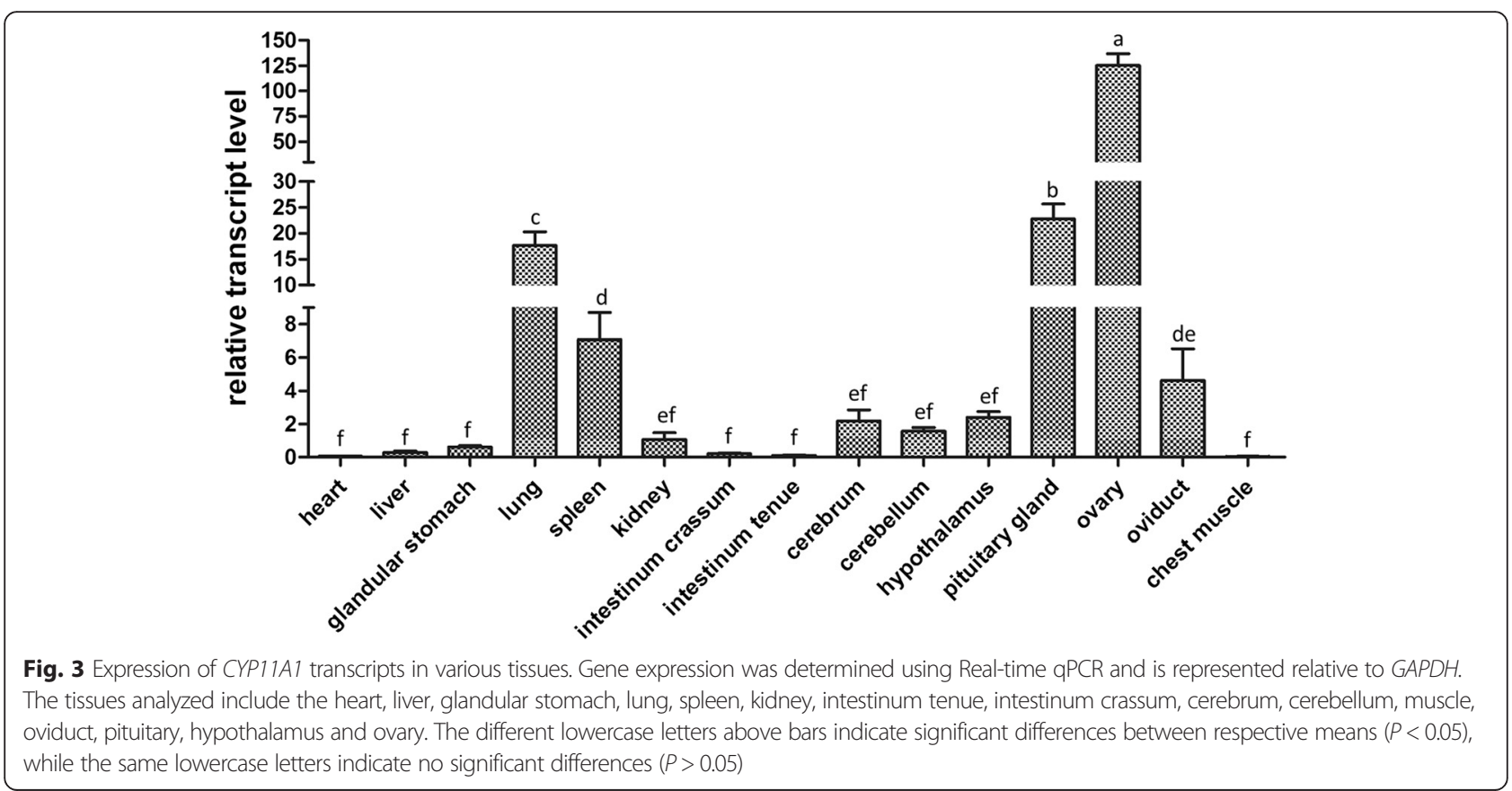




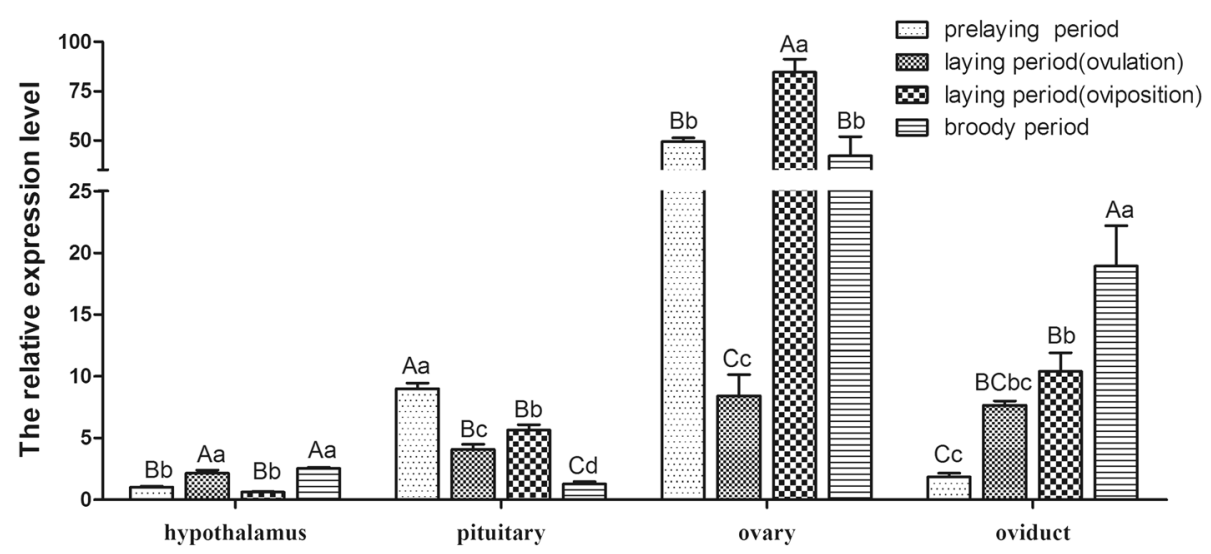

Fig. 4 Expression patterns of CYP11A1 during the reproductive cycle. The qPCR quantification of CYP11A1 transcripts during the prelaying, ovulation, oviposition, and broody periods. CYP11A1 expression was normalized to GAPDH. Different capital letters above bars indicate very significant differences between respective means $(P<0.01)$, while different lower case letters indicate significant differences $(P<0.05)$

periods . The expression of CYP11A was significantly higher in the examined reproductive tissues of Yangzhou geese in the ovulation period in pituitary and ovary tissues than that of Zhedong geese (Fig. 5).

\section{Discussion}

In this study, cDNAs encoding CYP11A1 were cloned from Chinese goose ovaries. The deduced amino acid sequence of CYP11A1 shows high identity with that of other birds and contains some structural domains typical of the cytochrome P450 superfamily, specifically a steroid-binding domain and a heme-binding domain [18]. Both domains appear to be well conserved among the different species, indicating that they may be critical for proper enzymatic activity of all P450scc.

As expected on the basis of the predicted goose CYP11A1 amino acid sequence, phylogenetic analysis clearly clustered goose CYP11A1 with other Phasianidae forms and showed that birds CYP11A1 appear to be significantly diverged from mammalian forms and fish forms.

CYP11A1 mRNA was expressed ubiquitously in every tissue analyzed except heart and muscle, albeit to different degrees. As expected, CYP11A1 mRNA was easily detected in reproductive tissues and endocrine tissues. These results are in agreement with recent molecular studies aimed at determining the temporal expression of CYP11A1 in mammals $[19,20]$. The expression of the CYP11A1 was previously well documented in tissues such as the adrenals, gonads, placenta [21, 22], pancreas [23], skin [24], gut [25], kidney [26] and certain areas of the brain [10], where its expression has been linked to steroidogenic activity. The relative abundance of specific transcripts at these various sites suggests that CYP11A1 could potentially play an important role in regulating

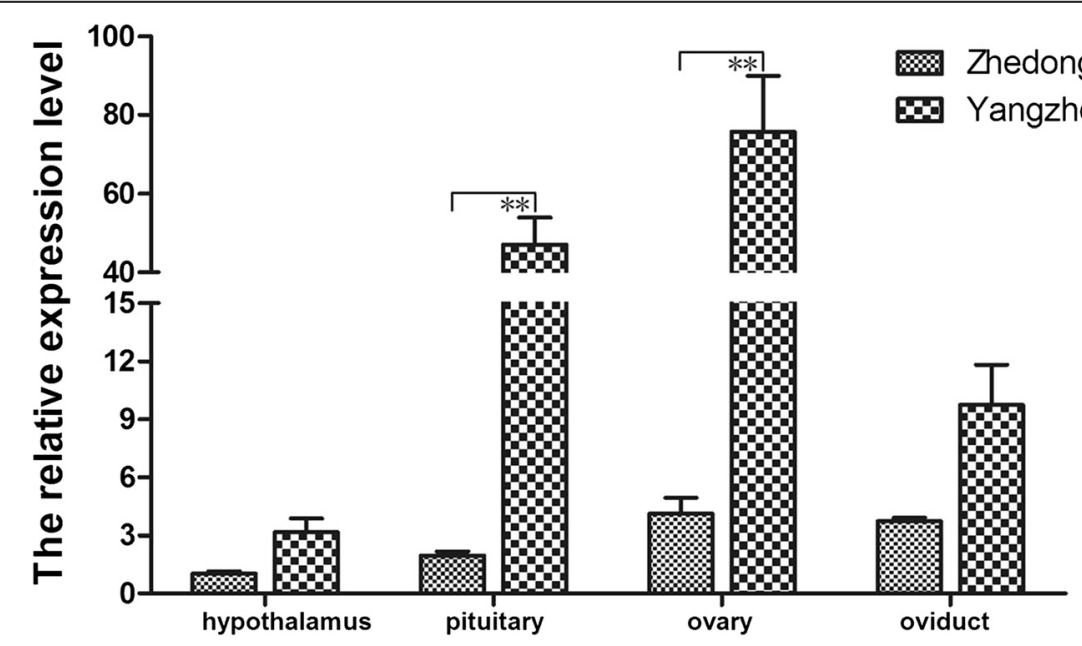

Fig. 5 Comparison of CYP11A1 mRNA expression between Zhedong geese and Yangzhou geese in ovulation period. Gene expression was determined using $\mathrm{qPCR}$ and is represented relative to GAPDH. Significant differences relative to controls are indicated with an asterisk $(P<0.01)$ 
local steroid hormone synthesis $[27,28]$. We also found CYP11A1 to be expressed in various nonendocrine tissues, including the lung, spleen, stomach, liver, brain, gut and kidney. During the last few years, CYP11A1 has been shown to be expressed in various tissues that are not involved in steroid synthesis. Sigel A et al. have elaborated CYP11A1 own ubiquitous roles [29].

The qPCR analysis revealed that CYP11A1 transcript abundance drastically changed in ovary, oviduct, and pituitary tissues during the different stages of the reproductive cycle. As expected, CYP11A1 mRNA levels were relatively low at ovulation compared with oviposition. CYP11A1 catalyzes the conversion of cholesterol to pregnenolone in the first step of steroid biosynthesis [30]. It has been reported in geese and hens that the levels of progesterone in the plasma peak 2 to $3 \mathrm{~h}$ before ovulation and then decrease $[30,31]$ which might be due to low CYP11A1 mRNA level. The higher CYP11A1 expression was observed in ovary and oviduct tissues during broodiness, which is in concordance with previous studies that showed that gonadal steroid levels are maintained at a high level in broody birds [32]. Interestingly, The CYP11A1 expression was high in pituitary than the oviduct during prelaying time. In contrast, the expression of gene was high in ovary/oviduct during oviposition, ovulation and brooding, but low in hypothalamus/pituitary (Fig. 4). There may be a feedback mechanism to control this gene/enzyme expression. CYP11A1 is an important enzyme to produce the progestin precursor required for the synthesis of estradiol [28]. We speculate the estradiol might effect on steroid hormone synthesis by hypothalamus-pituitary-gonad (HPG) axis. On the contrary, high concentrations of steroids might regulate CYP11A1 mRNA expression.

We also observed higher CYP11A1 expression in Yangzhou geese than in Zhedong geese during the ovulation period. Yangzhou geese are known for high egg production, while Zhedong geese show low egg production. Yangzhou geese might need to release more pregnenolone to ovulate, so the observed higher CYP11A1 expression levels may be required to ensure sufficient hormone secretion.

\section{Conclusions}

In summary, we present the molecular cloning and characterization of the goose $C Y P 11 A 1$, and analyze its expression during the goose reproductive cycle. The relatively low levels of CYP11A1 mRNA were detected at ovulation when compared with levels at oviposition. The higher mRNA expression was investigated during the ovulation period of Yangzhou geese than that of Zhedong geese. Our findings provides correlative evidence that CYP11A1 expression is important in reproduction activity.

\section{Abbreviations}

P450scc: side-chain cleavage cytochrome P450; CYP11A1: cholesterol side chain cleavage enzyme; RT-PCR: reverse transcription polymerase chain reaction; RACE: rapid amplification of CDNA ends; bp: base pair;

UTR: untranslated region; qPCR: quantitative polymerase chain reaction; GAPDH: glyceraldehyde-3-phosphate dehydrogenase;

HPG: hypothalamus-pituitary-gonad.

\section{Competing interests}

The authors declare that they have no competing interests.

\section{Authors' contributions}

Conceived and designed the experiments: GC and QX. Performed the experiments:. QX, YS and YC. Analyzed the data: QX, YS and GC. Contributed reagents/materials/analysis tools: $\mathrm{RL}, \mathrm{YZ}, \mathrm{YL}, \mathrm{ZH}$ and $\mathrm{WZ}$. Wrote the paper: $\mathrm{QX}$ and GC. All authors read and approved the final manuscript.

\section{Acknowledgments}

We are grateful to Jiangsu Lihua Animal Husbandry CO. LTD for offering the animal sample. This work received financial support from the earmarked fund for Modern Agro-industry Technology Research System (CARS-43-3), the Agricultural Science and Technology Independent Innovation Fund of Jiangsu Province (CX(13)2034) and the Priority Academic Program Development of Jiangsu Higher Education Institutions (2011-137).

Received: 31 July 2015 Accepted: 1 December 2015

Published online: 22 December 2015

\section{References}

1. O'Hara L, York JP, Zhang P, Smith LB. Targeting of GFP-Cre to the mouse Cyp11a1 locus both drives cre recombinase expression in steroidogenic cells and permits generation of Cyp11a1 knock out mice. PLoS One. 2014; 9(1), e84541

2. Kowalski Kl, Tilly JL, Johnson AL. Cytochrome P450 side-chain cleavage (P450scc) in the hen ovary. I. Regulation of P450scc messenger RNA levels and steroidogenesis in theca cells of developing follicles. Biol Reprod. 1991; 45(6):955-66.

3. Tilly JL, Kowalski Kl, Johnson AL. Cytochrome P450 side-chain cleavage (P450scc) in the hen ovary. II. P450scc messenger RNA, immunoreactive protein, and enzyme activity in developing granulosa cells. Biol Reprod. 1991;45(6):967-74.

4. Johnson A, Woods DC. Dynamics of avian ovarian follicle development: cellular mechanisms of granulosa cell differentiation. Gen Comp Endocrinol. 2009;163(1):12-7.

5. Sechman A, Pawlowska K, Hrabia A. Effect of 3,3',5-triiodothyronine and 3,5-diiodothyronine on progesterone production, CAMP synthesis, and mRNA expression of STAR, CYP11A1, and HSD3B genes in granulosa layer of chicken preovulatory follicles. Domest Anim Endocrinol. 2011;41(3):137-49.

6. Rangel PL, Rodriguez A, Rojas S, Sharp PJ, Gutierrez CG. Testosterone stimulates progesterone production and STAR, P450 cholesterol side-chain cleavage and LH receptor mRNAs expression in hen (Gallus domesticus) granulosa cells. Reproduction. 2009;138(6):961-9.

7. Chiu Chih-Hsien LC-W, Jong D-S, Kuo W-W, Ting LI, Wu L-S. Expression of Steroidogenic Enzymes and Related Protein in Follicles of Tsaiya Duck. J Agr Assoc China. 2007;8(5):456-69.

8. Chiu CH, Fei CY, Srinivasan R, Wu LS. Inhibitory effects of epidermal growth factor on progesterone production of ovarian granulosa cells in Tsaiya duck (Anas platyrhynchos var. domestica). Br Poult Sci. 2010;51(6):821-7.

9. Li Z, Johnson A. Regulation of P450 cholesterol side-chain cleavage messenger ribonucleic acid expression and progesterone production in hen granulosa cells. Biol Reprod. 1993;49(3):463-9.

10. Hammer F, Compagnone NA, Vigne JL, Bair SR, Mellon SH. Transcriptional regulation of $\mathrm{P} 450 \mathrm{scc}$ gene expression in the embryonic rodent nervous system. Endocrinology. 2004;145(2):901-12.

11. Shih M-CM, Chiu Y-N, Hu M-C, Guo C, Chung B-C. Regulation of steroid production: analysis of Cyp11a1 promoter. Mol Cell Endocrinol. 2011;336(1):80-4.

12. LaVoie HA, King SR. Transcriptional regulation of steroidogenic genes: STARD1, CYP11A1 and HSD3B. Exp Biol Med. 2009;234(8):880-907.

13. Guo IC, Shih MC, Lan HC, Hsu NC, Hu MC, Chung BC. Transcriptional regulation of human CYP11A1 in gonads and adrenals. J Biomed Sci. 2007;14(4):509-15. 
14. Quek SI, Chan WK. Transcriptional activation of zebrafish cyp1 1a1 promoter is dependent on the nuclear receptor Ff1b. J Mol Endocrinol. 2009;43(3):121-30

15. Xu Q, Zhang $Y$, Chen $Y$, Tong $Y Y$, Rong GH, Huang ZY, et al. Identification and Differential Expression of microRNAs in Ovaries of Laying and Broody Geese (Anser cygnoides) by Solexa Sequencing. PLoS One. 2014;9(2):e87920.

16. Xu Q, Zhao WM, Chen Y, Tong YY, Rong GH, Huang ZY, et al. Transcriptome Profiling of the Goose (Anser cygnoides) Ovaries Identify Laying and Broodiness Phenotypes. PLoS One. 2013:8(2):e55496.

17. Nomura O, Nakabayashi O, Nishimori K, Mizuno S. The cDNA cloning and transient expression of a chicken gene encoding cytochrome P-450scc. Gene. 1997:185(2):217-22.

18. Ni Y, Zhou Y, Lu L, Grossmann R, Zhao R. Developmental changes of FSH-R, LH-R, ER-beta and GnRH-I expression in the ovary of prepubertal ducks (Anas platyrhynchos). Anim Reprod Sci. 2007;100(3-4):318-28.

19. Vilchis F, Chavez B, Larrea F, Timossi C, Montiel F. The cDNA cloning and tissue expression of the cytochrome P450scc from Syrian hamster (Mesocricetus auratus). Gen Comp Endocrinol. 2002:126(3):279-86.

20. Watanabe KP, Kawai YK, Ikenaka Y, Kawata M, Ikushiro S, Sakaki T, et al. Avian cytochrome P450 (CYP) 1-3 family genes: isoforms, evolutionary relationships, and mRNA expression in chicken liver. PLoS One. 2013;8(9), e75689.

21. Schwartz JR, Roy SK. Developmental expression of cytochrome P450 side-chain cleavage and cytochrome P450 17 alpha-hydroxylase messenger ribonucleic acid and protein in the neonatal hamster ovary. Biol Reprod. 2000;63(6):1586-93.

22. Slominski A, Semak I, Zjawiony J, Wortsman J, Gandy MN, Li J, et al. Enzymatic metabolism of ergosterol by cytochrome p450scc to biologically active 17alpha,24-dihydroxyergosterol. Chem Biol. 2005;12(8):931-9.

23. Morales A, Cuellar A, Ramirez J, Vilchis F, Diaz-Sanchez V. Synthesis of steroids in pancreas: evidence of cytochrome P-450scc activity. Pancreas. 1999;19(1):39-44

24. Slominski A, Zjawiony J, Wortsman J, Semak I, Stewart J, Pisarchik A, et al. A novel pathway for sequential transformation of 7-dehydrocholesterol and expression of the P450scc system in mammalian skin. Eur J Biochem. 2004; 271(21):4178-88.

25. Cima I, Corazza N, Dick B, Fuhrer A, Herren S, Jakob S, et al. Intestinal epithelial cells synthesize glucocorticoids and regulate T cell activation. J Exp Med. 2004; 200(12):1635-46.

26. Dalla Valle L, Toffolo V, Vianello S, Belvedere P, Colombo L. Expression of cytochrome P450scc mRNA and protein in the rat kidney from birth to adulthood. J Steroid Biochem Mol Biol. 2004;88(1):79-89.

27. Xiao Y, Ni Y, Huang Y, Wu J, Grossmann R, Zhao R. Effects of kisspeptin-10 on progesterone secretion in cultured chicken ovarian granulosa cells from preovulatory (F1-F3) follicles. Peptides. 2011;32(10):2091-7.

28. Ahumada-Solórzano SM, Carranza ME, Pedernera E, Rodríguez-Méndez AJ, Luna M, Arámburo C. Local expression and distribution of growth hormone and growth hormone receptor in the chicken ovary: Effects of $\mathrm{GH}$ on steroidogenesis in cultured follicular granulosa cells. Gen Comp Endocrinol. 2012;175(2):297-310

29. Sigel A, Sigel H, Sigel RK. The ubiquitous roles of cytochrome P450 proteins: metal ions in life sciences. New York: John Wiley \& Sons; 2007.

30. Celebi F, Guven B. Plasma concentrations of 13,14-dihydro-15-keto PGF2alpha and progesterone during the oviposition cycle of the domestic goose (Anser anser domesticus). Poult Sci. 2001;80(2):225-7.

31. Sechman A, Staruszczak M, Rząa J. Comparison of Sex Steroid Concentration in Blood Plasma and Ovarian Follicles of White Leghorn and Greenleg Partridge Laying Hens. Ann Ani Sci. 2011;11(4):507-20.

32. Bedrak E, Harvey S, Chadwick A. Concentrations of pituitary, gonadal and adrenal hormones in serum of laying and broody white rock hens (Gallus domesticus). J Endocrinol. 1981;89(2):197-204.

\section{Submit your next manuscript to BioMed Central and we will help you at every step:}

- We accept pre-submission inquiries

- Our selector tool helps you to find the most relevant journal

- We provide round the clock customer support

- Convenient online submission

- Thorough peer review

- Inclusion in PubMed and all major indexing services

- Maximum visibility for your research

Submit your manuscript at www biomedcentral.com/submit
C BioMed Central 